\title{
The Effect of Pressure Controlled Ventilation on Pulmonary Mechanics in Prone Patients Undergoing Elective Spine Surgeries: Comparative Study with Volume Controlled Ventilation
}

\author{
AHMED E. YOUSSEF, M.Sc.; HASSAN MOHAMED, M.D.; IMAN FOUAD, M.D.; \\ NADER NOSHEY, M.D. and AHMED RAGAB, M.D. \\ The Department of Anaesthesiology, Faculty of Medicine, Cairo University
}

\begin{abstract}
Background: As patients turned into prone position experienced more decrease in lung compliance than those on supine position, this prospective, randomized study was designed to compare the effect of PCV and volume-controlled ventilation (VCV) on lung mechanics and heamodynamics in the prone position using the Wilson frame during elective lumbar spine surgery.

Patients and Methods: Sixty patients scheduled for elective lumbar spine surgery were randomly allocated to receive mechanical ventilation using either the VCV $(n=30)$ or PCV $(\mathrm{n}=30)$ mode. Respiratory variables (peak airway pressure, mean airway pressure, shunt fraction, alveolar-arterial oxygen gradient). Dynamic compliance (Cdyn) of the respiratory system was calculated as VT/ (Ppeak-PEEP). The alveolar dead space-to-tidal volume ratio (VD/VT) will be estimated using the Hardman and Aitkenhead equation: VD/VT=1. 135$\left(\mathrm{PaCO}_{2}-\mathrm{ETCO}_{2}\right) /\left(\mathrm{PaCO}_{2}-0.005\right)$.

Results: The Ppeak in the PCV group was lower than that in the VCV group throughout the study period ( $p$-value $=0.961$ and 0.0 .109 at supine position and prone position, respectively) and was increased at prone position compared with supine position in both groups. Cdyn was decreased from supine to prone position in both groups. However, the Cdyn in the PCV group was higher than that in the VCV group during the study period however it is only statistically significant after 1.5 and $2 \mathrm{hrs}$. The arterial oxygen tension was comparable between the 2 groups during the study period.

Conclusions: PCV provides lower Ppeak compared with VCV when the ventilator is set to deliver the same tidal volume and variable respiratory rate to maintain a constant end-tidal carbon dioxide tension in patients undergoing posterior lumbar spine surgery in the prone position using the Wilson frame.
\end{abstract}

Key Words: Prone position - Pressure-controlledventilation - Volume-controlled ventilation.

Correspondence to: Dr. Ahmed E. Youssef, The Department of Anaesthesiology, Faculty of Medicine, Cairo University

\section{Introduction}

PRONE positioning of a patient under anesthesia is a safe way of ensuring optimum surgical access for a number of procedures, providing that the risks are fully understood. Common procedures requiring prone positioning are back surgery, pilonoidal sinus surgery and some types of ankle surgery e.g Achilles tendon repair. An understanding of the changes in physiology and the particular risks associated with the prone position is vital eg: Cardiovascular system: The most important feature of turning a patient prone under anesthesia is a drop in cardiac output. Respiratory system: Prone positioning has a broadly positive effect on the respiratory system providing that abdominal compression is avoided [1]

Functional residual capacity and arterial oxygen tension both increase. This is partially the reason why prone positioning [2] has been used in intensive care settings for patients with poor lung function when an anesthetized patient is turned to the prone position, dynamic compliance (Cdyn) decreases and peak airway pressure (Ppeak) increases and Potential sources of injury.

There are a number of body structures that can be injured these are generally as a result of direct pressure to structures on which body weight would not normally rest e.g.: Eyes, nose and nerves [3].

The earliest mechanical ventilators used on humans were pressure controllers. They were not truly pressure-limited; rather they were pressurecycled, terminating the inspiratory phase when a set pressure was achieved. However pressure preset ventilation fell from favour because of the inability to monitor delivered tidal volume (VT) 
and to control minute ventilation (VE) [4]. New ventilators that used volume-control were developed. This allowed clinicians better control and regulation of both VT and VE [я. During anesthesia the use of volume-controlled ventilation $(\mathrm{VCV})$ is common, as this has been the only available mode on ventilators for a long time. This mode utilizes a constant flow to deliver a target tidal volume (VT) and thus insures a constant minute ventilation, although this may necessitate high-pressures in certain conditions. The mechanical consequences of reduced lung compliance and chest wall compliance (acute respiratory distress syndrome ARDS, obesity) added to the reduction of functional residual capacity induced by the surgery (muscle relaxation, trendelenburg, pneumoperitoneum) explain both the impaired alveolar ventilation and the subsequent high-pressure [6-8]

Debate over the most efficient and safest control mode has continued ever since [9].

\section{Patients and Methods}

This study was done in the Neurosurgical Theater in Kasr El-Aini Hospital including 60 patients suffering from lumber disc prolapse, after obtaining informed written consent from the patients and approval of the Ethical and Scientific Committee of Anesthesia Department in Cairo University. This study was held between 2013 to 2014.

\section{Inclusion criteria:}

- Adult patients of both sex (20-50 years old).

- Patients undergoing spine surgeries in prone position.

- Patients of American Society of Anesthesiologists' physical status class I \& II.

- Patients with ideal body weight (body mass index 19:25 kg/m2).

\section{Exclusion criteria:}

- Patient refusal.

- Patient with obstructive (e.g. chronic obstructive pulmonary diseases, bronchial asthma) or restrictive chest problems (e.g. Pulmonary fibrosis, pregnant patients) or deformity.

- Patients with cardiovascular diseases (e.g. uncont-rolled hypertention, ischemic heart diseases, mild to moderate valvular disease).

\section{Randomization of study groups:}

The patients were randomly allocated into two equal groups each one includes 30 patients by closed envelope chosen by the surgeon.
- Group V: Ventilated by volume controlled ventilation mode with a tidal volume $10 \mathrm{ml} / \mathrm{kg}$.

- Group P: Ventilated by pressure controlled ventilation mode, adjusting the peak airway pressure to deliver tidal volume $10 \mathrm{ml} / \mathrm{kg}$ on supine position and readjusted after turning to prone position to deliver the same tidal volume.

\section{Anesthetic technique:}

All patients were fasting from for 6 to 8 hours before surgery. On the day of surgery all patients were premedicated with midazolam $2 \mathrm{mg} I V$, and ranitidine $50 \mathrm{mg}$ administered IV(slowly) $30 \mathrm{~min}$ utes before arriving into the operating $\operatorname{room}(\mathrm{OR})$.

On arrival to operating room ideal body weight estimated from the following equation: $50+0.91 \mathrm{x}$ (height in $\mathrm{cm}-152.4$ ) for men and 45.5+0.91 x (height in cm-152.4) for women [10]

On the operating table monitors were applied to the patients for continuous measuring of the heart rate and rhythm by ECG, oxygen saturation using pulse oxymetry and non invasive blood pressure by oscillometry.

For all patients, IV induction using propofol of $2 \mathrm{mg} / \mathrm{kg}$, fentanyl of $2 \mathrm{p}, \mathrm{g} / \mathrm{kg}$ and atracurium $0.5 \mathrm{mg} / \mathrm{kg}$. Muscle relaxation was confirmed 3-5 minutes after administering atracurium.

A wire-reinforced endotracheal tube was used, its site was confirmed by auscultation and continuous monitoring of end tidal $\mathrm{CO} 2$ using capnogram. Anesthesia was maintained by $\mathrm{O}_{2} 2 \mathrm{~L} / \mathrm{min}\left(\mathrm{Fio}_{2}\right.$ $100 \%$ ), isoflurane $1 \%$ inspired concentration, continuous IV infusion of atracurium at a rate of $0.5 \mathrm{mg} / \mathrm{kg} / \mathrm{hr}$. Morphine $0.1 \mathrm{mg} / \mathrm{kg}$ was given.

Mechanical ventilation was set to deliver the tidal volume (VT) in the volume controlled ventilation (VCV) group and the Ppeak (peak airway pressure) in the pressure controlled ventilation (PCV) group was set initially to deliver a VT of $10 \mathrm{~mL} / \mathrm{kg}$ of ideal body weight. The RR in both groups adjusted to maintain an end tidal carbon dioxide tension $\left(\mathrm{ETCO}_{2}\right)$ between 33 and $36 \mathrm{~mm}$ $\mathrm{Hg}$, and the inspiratory to expiratory time (I/E) ratio was set to $1: 2$.

Radial artery cannulation using a 20 gauge arterial catheter to allow for arterial blood sampling. A urinary catheter inserted to measure hourly urine output.

After positioning patients in the prone position on the Wilson frame, the Ppeak was reset to match the initial expired VT in the PCV group. 
At the end of the operation and repositioning the patient to supine position emergence and reversal of muscle relaxant using Atropine $0.2 \mathrm{mg} / \mathrm{kg}$ and neostigmine $0.04 \mathrm{mg} / \mathrm{mg}$.

After extubation, patients remained one hour in the recovery room then plain postero-anterior chest $\mathrm{x}$ ray done to detection occurrence of any basal atelectasis in both groups.

\section{Measured Variables:}

Respiratory variables:

1- Peak airway pressure:(Continously measured but recorded after induction of anesthesia in the supine position (Tsupine) and 30 minutes after the prone positioning (Tprone) then every 30 minutes).

2- Shunt fraction, alveolar-arterial oxygen gradient: (estimated after induction of anesthesia in the supine position (Tsupine) and 30 minutes after the prone positioning (Tprone) then every 30 minutes from the following equations).

Shunt fraction (the physiological shunt is rarely over 4\%). Calculated from the equation:

$$
\mathrm{Qs} / \mathrm{Qt}=\left(\mathrm{CcO}_{2}-\mathrm{CaO}_{2}\right) /(\mathrm{CcO} 2-\mathrm{CvO} 2)
$$

Where (Qs) is the shunted blood (blood not participating in gas exchange) (QT) is the total cardiac output, $\left(\mathrm{CvO}_{2}\right)$ is oxygen content of the venous blood, $\left(\mathrm{CaO}_{2}\right)$ is oxygen content of the arterial blood, $\left(\mathrm{CcO}_{2}\right)$ is the content of oxygen in pulmonary capillary and it is estimated by plugging in $100 \%$ as the saturation (1.00 for the math) since the $\mathrm{PcO}_{2}$ (pulmonary capillary $\mathrm{PO}_{2}$ ) can be assumed to be high enough to assure $100 \%$ saturation.

The $\mathrm{PcO}_{2}$ itself cannot be directly measured so we use $\mathrm{PAO}_{2}$ (from the alveolar air equation) in its place:

$$
\mathrm{PAO}_{2}=\left(\mathrm{FiO}_{2} *\left(\mathrm{P}_{\mathrm{atmos}}-\mathrm{P}_{\mathrm{H} 2 \mathrm{O}}\right)-\left(\mathrm{PaCO}_{2} / \mathrm{RQ}\right) .\right.
$$

The $\mathrm{FiO}_{2}$ is the fraction of inspired oxygen (usually as a fraction, but entered here as a percentage for ease of use).

$\mathrm{P}_{\text {atmos }}$ is the ambient atmospheric pressure, which is 760 torr at sea level. $\mathrm{P}_{\mathrm{H} 2 \mathrm{O}}$ is water vapor pressure at $37^{\circ} \mathrm{C}$ and is equal to $47 \mathrm{mmHg}$. The respiratory quotient (RQ) is the ratio of $\mathrm{CO} 2$ eliminated divided by the $\mathrm{O}_{2}$ consumed, and its value is typically 0.8 but can range from 0.7 to 1.0 and the $\mathrm{PaCO}_{2}$ is the $\mathrm{CO} 2$ partial pressure in the arterial blood.

This means that $\mathrm{CcO}_{2}=" 1.39 " \times \mathrm{Hb}+0.003 \times \mathrm{PAO}_{2}$
3-Arterial blood gas andvenous blood gas analysis: (After induction of anesthesia in the supine position (Tsupine) and 30 minutes after the prone positioning (Tprone) then every $30 \mathrm{~min}$ utes).

4- Dynamic compliance: (Cdyn) of the respiratory system was calculated(after induction of anesthesia in the supine position (Tsupine) and 30 minutes after the prone positioning (Tprone) then every 30 minutes) as VT/(Ppeak-PEEP) [10].

5- The alveolar dead space-to-tidal volume ratio (VD/VT) was estimated: (After induction of anesthesia in the supine position (Tsupine) and 30 minutes after the prone positioning (Tprone) then every 30 minutes) using the Hardman and Aitkenhead equation: VD/VT $=1.135 \times\left(\mathrm{PaCO}_{2}-\right.$ $\left.\mathrm{ETCO}_{2}\right) /\left(\mathrm{PaCO}_{2}-0.005\right)$ Normal VD/VT is less than $0.33(<33 \%)$.

\section{Results}

Sixty patients were enrolled in the study.

Only 57 patients completed the study there were 26 male and 31 female patients with a mean age of $53.17 \pm 7.27$ years, all patient were ASA 1 and 2 .

There were no statistical differences in age ( $p$ value 0.056 ), male to female ratio ( $p$-value 0.435$)$, and BMI between the two groups ( $p$-value 0.595).

Table (1): Patient characteristics. Data are presented as mean

\begin{tabular}{|c|c|c|}
\hline & $\begin{array}{c}\text { Volume controlled } \\
\text { ventilation }\end{array}$ & $\begin{array}{l}\text { essure controlled } \\
\text { ventilation }\end{array}$ \\
\hline Age (year) & $53.71 \pm 7.27$ & $45.78 \pm 7.45$ \\
\hline Weight (Kgm) & $65.25 \pm 7.87$ & $64.11 \pm 9.45$ \\
\hline Hight (Cm) & $165.38 \pm 11.94$ & $161.11 \pm 10.54$ \\
\hline BMI $\left(\mathrm{kgm} / \mathrm{m}^{2}\right)$ & $23.87 \pm 1.68$ & $24.59 \pm 1.17$ \\
\hline $\begin{array}{l}\text { Duration of surgery } \\
\text { (hours) }\end{array}$ & $2.36 \pm 0.42$ & $2.44 \pm 0.38$ \\
\hline
\end{tabular}
\pm standard deviation $(\mathrm{SD})$

Table (2): Gender distribution in both groups.

\begin{tabular}{lcclll}
\hline & \multicolumn{5}{c}{ Group } \\
\cline { 2 - 3 } & $\begin{array}{c}\text { Volume controlled } \\
\text { ventilation }\end{array}$ & & \multicolumn{2}{c}{$\begin{array}{c}\text { Pressure controlled } \\
\text { ventilation }\end{array}$} \\
\cline { 2 - 3 } & Count & $\%$ & & Count & $\%$ \\
\hline Sex: & 13 & 50.0 & & 18 & 66.6 \\
Female & 15 & 50.0 & & 11 & 33.3 \\
Male & & & & & \\
\hline
\end{tabular}




\section{As for ventilatory and oxygenation parameters:}

1- The peak airway pressure (Ppeak): There was no statistical differences between the two groups in both; supine position: Mean peak airway pressure was $20 \mathrm{mmHg}$ in volume controlled group and $19 \mathrm{mmHg}$ in pressure controlled group ( $p$-value 0.961),

In prone position: Mean peak airway pressure was $25 \mathrm{mmHg}$ in volume controlled group and $22.12 \mathrm{mmHg}$ in pressure controlled group ( $p$-value 0.109 ).

2- Respiratory rate:(Breaths $\backslash$ min.) in the PCV group mean \pm SD $(10.1 \pm 1.0)$ in supine position and $(9.8 \pm 1.0)$ in prone position, was not significantly higher compared with the VCV group $(9.9 \pm 1.6)$ in supine position and $(8.9 \pm 1.3)$ in both groups.

3- Tidal volume $(\mathrm{ml})$ : In volume controlled mean \pm SD in supine position (589 \pm 90$)$ and $(566 \pm 93)$ in prone position and in pressure controlled group it was (568 \pm 139$)$ in supine position and $(507 \pm 121)$ in prone position.

4- Minute volume: (L/min.) mean $\pm \mathrm{SD}$ was $(5.6 \pm$ $1.3)$ during supine position and (5.2 \pm 1.2$)$ during prone position in volume controlled group and in pressure controlled group it was $(5.6 \pm 1.5)$ and (4.9 \pm 1.2$)$ during supine and prone position respectively, so both VT and MV decreased after prone positioning in both groups but with no statistically significance.

\section{5- Dynamic compliance (Cdyn): $\left(\mathrm{mL} / \mathrm{cm} \mathrm{H}_{2} \mathrm{O}\right)$}

-Was decreased with no statistically significant on turning patient from supine position to prone position in both study groups.

- Cdyn in PCV was higher than in VCV but with no statistic significant as shown in graph.

- Mean \pm SD was $(27.91 \pm 6.67)$ and (3 $1.89 \pm 6.55)$ during supine position in volume controlled group and pressure controlled group respectively ( $p$ value 0.335$)$

- (21.96 \pm 4.21$)$ and (27.42 \pm 5.73$)$ during prone position for volume controlled group and pressure controlled group respectively ( $p$-value 0.075 ).

However, after 1.5hrs and $2 \mathrm{hrs}$ of prone positioning: Cdyn in PCV group was statistically significant higher than VCV as shown in graph.

- Cdyn in $\left(\mathrm{mL} / \mathrm{cm} \mathrm{H}_{2} \mathrm{O}\right)$ difference between between VCV and PCV during Prone position, every $30 \mathrm{~min}$.
- Cdyn as (mL/cm H2O) 1.5 hour after turning patient to prone position $p$-value 0.043 ).

- Mean \pm SD (22.52 \pm 4.21$)$ and (32 \pm 4.93$)$ for volume and pressure controlled group respectively.

- 2 hours after turning into prone position ( $p$-value 0.026 ).

- Mean \pm SD $(26.1 \pm 2.76)$ and (34.9 \pm 4.56$)$ for volume and pressure controlled group respectively.

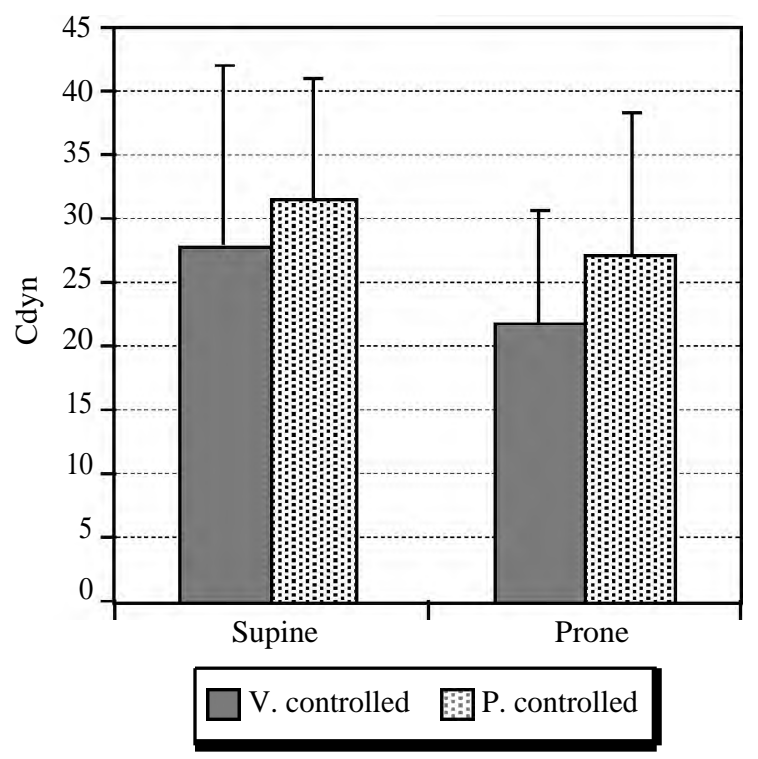

Fig. (1): Changes in Cdyn in $\left(\mathrm{mL} / \mathrm{cm} \mathrm{H}_{2} \mathrm{O}\right)$ from supine to prone position in both groups.

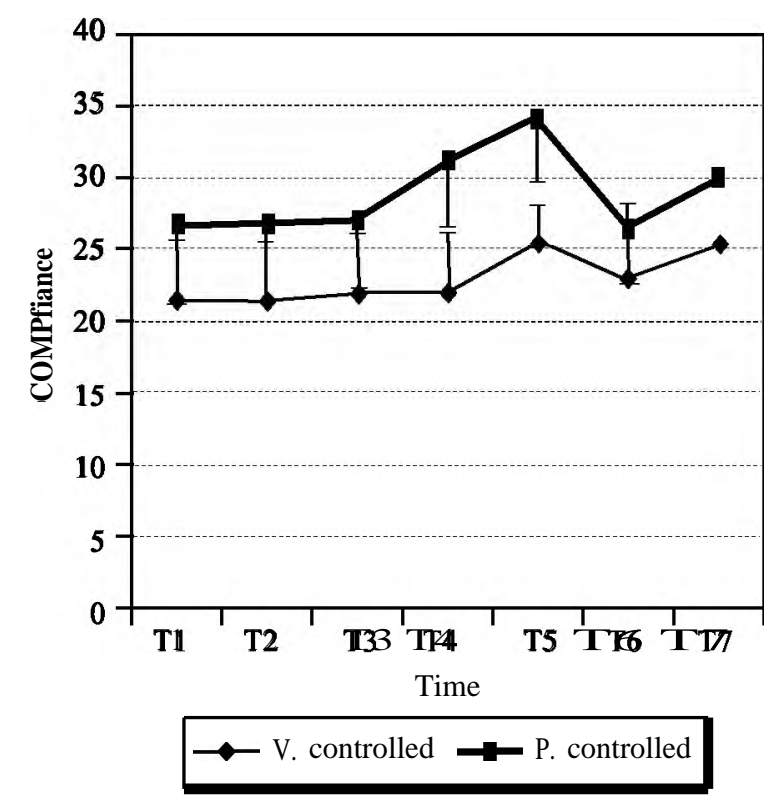

Fig. (2): Graph showing the statistically difference between both groups in Cdyn only after $1.5 \mathrm{hr}$ and $2 \mathrm{hrs}$ of Tprone. 


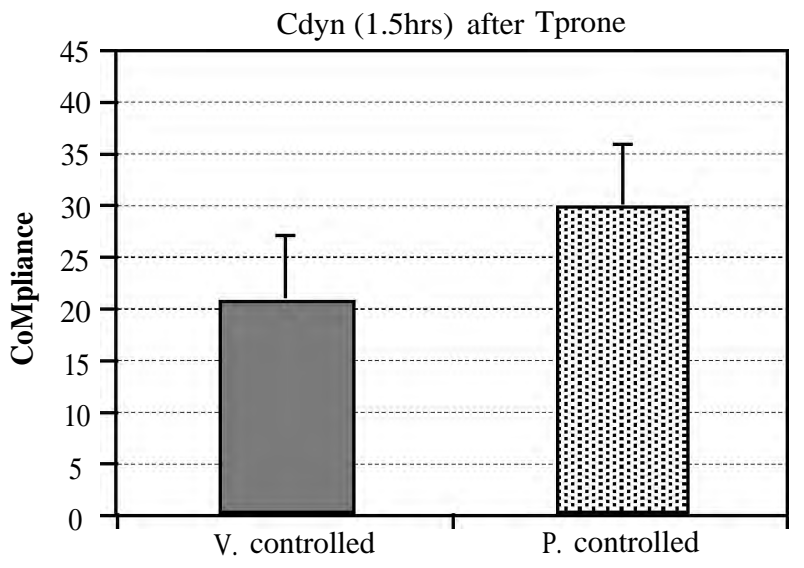

V. controlled P. controlled

Fig. (3): Cdyn in $\left(\mathrm{mL} / \mathrm{cm} \mathrm{H}_{2} \mathrm{O}\right)$ after $1.5 \mathrm{hrs}$. of prone position in both groups.

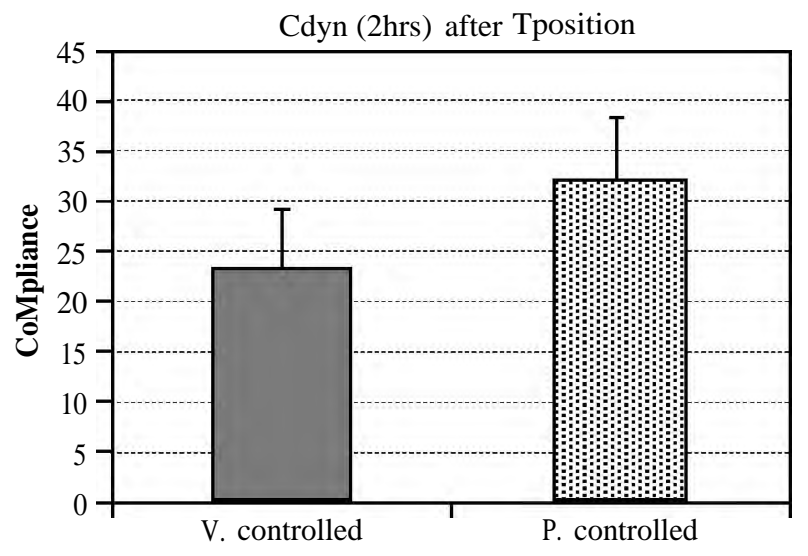

V. controlled 堌 P. controlled

Fig. (4): Cdyn in (mL/cm $\left.\mathrm{H}_{2} \mathrm{O}\right)$ after 2 hrs. of prone position in both groups.

6- $\mathrm{PaO}_{2}(\mathrm{mmHg})$ : Were comparable between both group through out the study.

7- VD/VT $(\%)$ were comparable between the 2

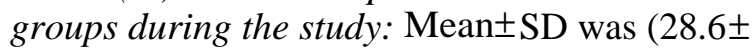
$5.4)$ and $(27.1 \pm 3.8)$ for volume controlled group in supine and prone position respectively and $(27.3 \pm 4.3)$ and $(26.8 \pm 4.5)$ in supine and prone position respectively.

8- Oxygen saturation $\left(\mathrm{SpO}_{2}\right)$ : Was maintained above $96 \%$ in all patients during the study period.

9- There was no statistical differences between two groups concerning shuntfraction\%: In supine position mean $\pm S D$ was $(2.3 \pm 0.22)$ in supine position and $(2.42 \pm 0.26)$ in prone position and $p$-value was ( $p$-value 0.773$)$ and ( $p$-value 0.7$)$ for both supine and prone position respectively.

\section{Discussion}

When an anesthetized patient is turned to the prone position, $\mathrm{ETCO}_{2}$ decreases and peak airway pressure (Ppeak) increases unless the abdomen hangs [11-13]. The Wilson frame is a curved frame that supports the chest and pelvis along the lateral edges. Even though the frame partially compresses the anterior abdominal wall and therefore does not allow the abdomen to hang completely. This in turn may increases Ppeak and decreases Cdyn [13]

Authors hypothesized that, patients in the PCV group would have lower Ppeak compared with the VCV group when they are turned to the prone position, if the same tidal volume is to be delivered with variable respiratory rate (RR) to maintain a constant end-tidal CO 2 [14]

Therefore, this study was designed to compare the effect of PCV and VCV on lung mechanics in the prone position using the Wilson frame during posterior lumbar spine surgery.

As regard respiratory variables; in our study, PCV was used to attenuate the increase in Ppeak during the prone position peak was decreased but with no statistically significant (in supine position mean peak airway pressure was $20 \mathrm{cmH}_{2} \mathrm{O}$ in volume controlled group and $19 \mathrm{cmH} 2 \mathrm{O}$ in pressure controlled group, in prone position mean peak airway pressure was $25 \mathrm{cmH}_{2} \mathrm{O}$ in volume controlled group and $22 \mathrm{cmH}_{2} \mathrm{O}$ in pressure controlled group) which agrees with Mirum Kim et al., [15] that found Ppeak increased after prone positioning in both groups. Ppeak in PCV group was lower than in VCV group (Ppeak $\left(\mathrm{cmH}_{2} \mathrm{O}\right)$ [15]

On the other hand Palmon SC et al., [13] research on the effect of the prone position on pulmonary mechanics; Seventy-seven adult patients that were divided into three groups according to body mass index: Normal <or $=27 \mathrm{~kg} / \mathrm{m} 2$, heavy $28-31 \mathrm{~kg} / \mathrm{m} 2$ and obese $>$ or $=32 \mathrm{~kg} / \mathrm{m} 2$.

Patients were placed in the prone position, a Wilson frame was used, they found that the Ppeak in the obese group (BMI $>32 \mathrm{~kg} / \mathrm{m} 2$ ) was significantly higher than that in the normal group (BMI $\geq 27 \mathrm{~kg} / \mathrm{m}^{2}$ ) in the supine and prone positions during VCV; Mean \pm SD: (normal group $19 \pm 3$ to $25 \pm 5 \mathrm{~cm}$ $\mathrm{H}_{2} \mathrm{O}$ ) during both supine and prone positions respectively and obese group was $27 \pm 4$ to $34 \pm 7 \mathrm{~cm}$ $\mathrm{H} 2 \mathrm{o}$ ) in supine and prone position respectively. Patients with a BMI $>30 \mathrm{~kg} / \mathrm{m} 2$ were excluded from our study to avoid additional confounding factors, and further studies is needed to elucidate the difference between VCV and PCV with regard to pulmonary mechanics in obese patients [13]. 
Casati, et al., [16] who did their study on one hundred and five ASA I-II patients, scheduled for elective surgical procedures were studied in order to evaluate the effect of different surgical positions on physiological pulmonary dead space and arterial to end-tidal carbon dioxide gradient.

Patients were divided into four groups according to their position on the operating table: Supine position (acting as control group, $n=33$ ), 20 degree Trendelenburg position, lateral position and prone position with convex saddle frame,they found that the arterial to ETCO2 gradient was higher in the prone position compared with the supine position and so RR decreased in prone position [16]

Also agree with Magi, et al., [17] who did a Prospective study, to compare $\mathrm{PaCO} 2, \mathrm{ETCO}_{2}$, $\mathrm{pH}$, Ppeak in a group of 10 patients undergoing elective intervention for lumbar disk herniation in prone position and in a control group of 10 patients undergoing interventions for elective non traumatologic orthopaedic surgery of the lower limbs in supine position; reported that the arterial to ETCO 2 gradient was higher in the prone position compared with the supine position ; mean $\mathrm{PaCO} 235.26 \mathrm{mmHg}$ (SD 3.045), mean $\mathrm{ETCO}_{2} 3.46 \mathrm{mmHg}$ (SD 1.898) in supine group and prone group: Mean $\mathrm{PaCO} 2$ $30.3 \mathrm{mmHg}$ (SD 5.819), mean $\mathrm{ETCO}_{2} 1.4 \mathrm{mmHg}$ (SD 4.445) [17].

As RR adjustment was based on $\mathrm{ETCO}_{2}$, the decrease in $\mathrm{ETCO}_{2}$ must have resulted in the decrease in RR.

Palmon et al., [13] have reported an $18 \%$ decrease in Cdyn (dynamic compliance) when patients were turned to the prone position on the Wilson frame during VCV. This is consistent with the results of our study, in which the Cdyn decreased by about $20 \%$ in the VCV group after prone positioning.

But in our study the Cdyn in the PCV group was significantly higher compared with the VCV group only during prone positioning [13]

These results are dis-simmilar to those of a recent study done by Choi et al., [18] on Eighteen patients, no major obstructive or restrictive pulmonary disease, were allocated randomly in two groups. In the first group, one lung ventilation was started by VCV and the ventilator was switched to PCV after 30 minutes. In the second group, the modes of ventilation were performed in the opposite order in the prone position, they found that PCV fail to provide advantages compared with VCV with regard to respiratory variables including pul- monary compliance in both groups. But this is study was performed on patient with one lung ventilation needed surgeries in contrary to our study [18].

Also in this study we found that there is no statistical difference in shunt fraction between supine position ( $p$-value 0.773 ) and prone position ( $p$-value 0.7) which is disagree with Pappert et al19 which was found that prone positioning caused a decrease in shunt perfusion of $11 \pm 5 \%$ and a concomitant increase of normal VA/Q (ventilation/perfusion) by $12 \pm 4 \%$ after $30 \mathrm{~min}$ in most of patients [19].

In conclusion, finally from this study we can conclude that PCV may offer a better option for patients receiving anaesthesia in prone position compared to VCV. This is due to its superior effect on lung compliance specially after $1.5 \mathrm{hr}$ and $2 \mathrm{hrs}$ duration of surgery in such position. Further studies are needed including larger number of patients to prove such benefit.

\section{References}

1- EDGCOMBE H., CARTER K. and YARROW S.: Anaesthesia in the prone position. Br. J. Anaesth., 100 (2): 165183, 2008.

2- MACINTYRE N.R.: New modes of mechanical ventilation. Clin. Chest. Med., 17: 411-421, 1996.

3- KNIGHT D.J. and MAHAJAN R.P.: Patient positioning in anaesthesia. Contin Educ Anaesthesia, Crit. Care. Pain, 4 (5): 160-163, 2004.

4- WOOLLAM C.H.:The development of apparatus for intermittent negative pressure respiration. Anaesthesia, 31 (5): 537-547, 1976.

5- CAMPBELL R.S. and DAVIS B.R.: Pressure-controlled versus volume-controlled ventilation: Does it matter? Respir. Care., 47 (4): 416-424; discussion 424-426, 2002.

6- ADAMS J.P. and MURPHY P.G.: Obesity in anaesthesia and intensive care. Br. J. Anaesth., 85 (1): 91-108, 2000.

7- SPRUNG J., WHALLEY D.G., FALCONE T., WARNER D.O., HUBMAYR R.D. and HAMMEL J.: The impact of morbid obesity, pneumoperitoneum, and posture on respiratory system mechanics and oxygenation during laparoscopy. Anesth. Analg., 94 (5): 1345-1350, 2002.

8- AMATO M.B., BARBAS C.S., MEDEIROS D.M., et al.: Beneficial effects of the \& quot; open lung approach \& quot; with low distending pressures in acute respiratory distress syndrome. A prospective randomized study on mechanical ventilation. Am. J. Respir. Crit. Care. Med., 152 (6 Pt 1): 1835-1846, 1995.

9- MERCAT A., GRAÏNI L., TEBOUL J.L., LENIQUE F. and RICHARD C.: Cardiorespiratory effects of pressurecontrolled ventilation with and without inverse ratio in the adult respiratory distress syndrome. Chest., 104 (3): 871-875, 1993. 
10-ANDREW J.: DIONNE The Little Black Book of Hospital Medicine (Little Black Book) (Jones and Bartlett's Little Black Book) ch.inflamatory lung disorders, p425, 2010.

11- EDGCOMBE H., CARTER K. and YARROW S.: Anaesthesia in the prone position. Br. J. Anaesth., 100 (2): 165$183,2008$.

12- MANNA E.M., IBRAHEIM O.A., SAMARKANDI A.H., ALOTAIBI W.M. and ELWATIDY S.M.: The effect of prone position on respiratory mechanics during spinal surgery. Middle. East. J. Anaesthesiol., 18 (3): 623-630, 2005 .

13-PALMON S.C., KIRSCH J.R., DEPPER J.A. and TOUNG T.J.: The effect of the prone position on pulmonary mechanics is frame-dependent. Anesth. Analg., 87 (5): 1175 1180,1998 .

14- STEWART T.E., MEADE M.O., COOK D.J., et al.: Evaluation of a ventilation strategy to prevent barotrauma in patients at high risk for acute respiratory distress syndrome. Pressure- and Volume-Limited Ventilation Strategy Group. N. Engl. J. Med., 338 (6): 355-361, 1998.

15- KIM M., KIM J., KWON S.H. and KIM G-H.: Pressure controlled vs. volume controlled ventilation during prone position in high-level spinal cord injury patients: A preliminary study. Korean. J. Anesthesiol., 67 (Suppl): S43S45, 2014.

16- CASATI A., SALVO I., TORRI G. and CALDERINI E. Arterial to end-tidal carbon dioxide gradient and physiological dead space monitoring during general anaesthesia: Effects of patients' position. Minerva. Anestesiol., 63 (6): 177-182, 1997.

17- MAGI E., MULTARI G., RECINE C ., et al.: Difference between arterial and end-tidal carbon dioxide tension during surgery of lumbar herniated disk in general anesthesia. Minerva Anestesiol., 381-386, 1994.

1 8- CHOI Y.S., SHIM J.K., NA S., HONG S.B., HONG Y.W and OH Y.J.: Pressure-controlled versus volume-controlled ventilation during one-lung ventilation in the prone position for robot-assisted esophagectomy. Surg. Endosc., 23 (10): 2286-2291, 2009

19- PAPPERT D., ROSSAINT R., SLAMA K., GRÜNING T. and FALKE K.J.: Influence of positioning on ventilation-perfusion relationships in severe adult respiratory distress syndrome. Chest., 106 (5): 1511-1516, 1994.

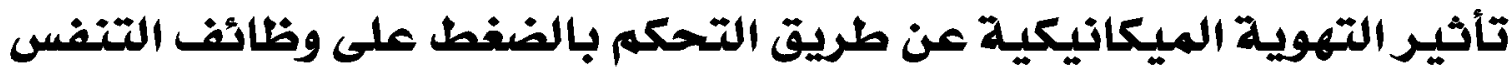

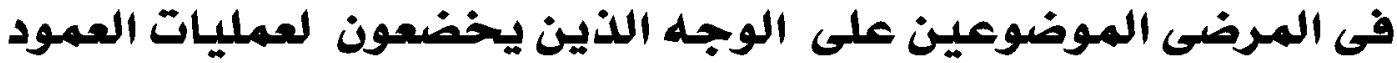

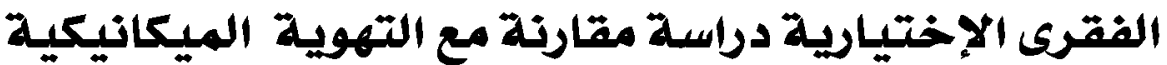 عن طريق التحكم بالحجم دئم التهويا
}

\author{
عند وضع المريض تصت تأثير المخدر على الوجه بإستخدام هيكل ويلسون فإن الليونة الديناميكية للرئة تقل وتزداد قيمة ضفط \\ الهواء داخل الممرات الهوائية. \\ أن التنفس الصناعى عن طريق التحكم بالضغط يقلل من قيمة ضغط الهواء داخل الممرات الهوائية. \\ إن الهدف من هذه الدراسة هو التهوية الميكانيكية للرئة عن طريق التحكم بالحجم والتهوية الميكانيكية للرئة عن طريق التحكم

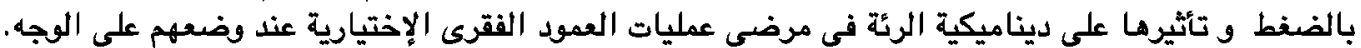 \\ ادرج فى هذه الدراسة .7 من المرضى أجريت لهم جراحات العمود الفقرى الأختيارية وتم توزيعهم عشوائياً على مجموعتين

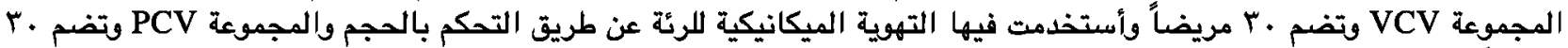

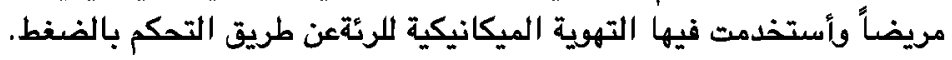 \\ النتائج : .7 مريض استكملوا الدراسة، حجم الهواء الكلى وحجم الهواء في الد قيقة وضغط ثانى أكسيد الكريهن في هواء الزفير \\ لم يظروا فروقاً هامة بين المريخ المبوعتين.

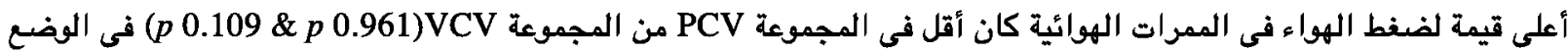

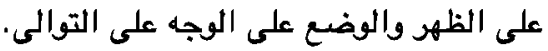 \\ الليونة الدينا ميكية للرئة انخفاض في كلا المجموعتين ما بين الوضـع على الظهر و الوضع على الوجه. ولكنها أعلى في مجموعة PCV

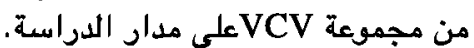 \\ وأظهرت فروقاً ها مة بعد ساعة ونصف وبساعتين من الوضع على الوجه (0.023 p \& 0.26 p) على التوالى. \\ ضغط الاكسجين في الدم لم يظروا فروقاً هامة بين المجموعتين.
}

